Citizenship Studies,

Vol. 9, No. 4, 423-438, September 2005

Routledge

Taylor \& Francis Group

\title{
Getting Carded: Border Control and the Politics of Canada's Permanent Resident Card
}

\author{
SIMONE BROWNE \\ OISE/University of Toronto, Department of Sociology and Equity Studies in Education, Toronto, Canada
}

\begin{abstract}
This article is concerned with the ways in which border control has been reconstituted through Canada's Permanent Resident Card (PRC). Some questions examined with this paper include: how did the PRC come to exist as a technology of border control? Does it function as a symbol of the Canadian nation-state's imperative to manage transnational movement and access to the geopolitical space of the nation and, if so, how? Through what means does the PRC and the events surrounding its introduction and use facilitate processes of serialization and racialization? Does the PRC, as a technique of reason of state, do the work of producing the category "responsible immigrants"? The notions of "economies of bodies" and "bordering" are important here. "Bordering" opens up the concept of the border from a fixed place to a verb, or a process. Given this, bordering does not only occur at the territorial boundaries of the nation-state, it can also be internal to it. By examining how the category of "permanent resident" is organized, gains meaning and is maintained, this article demonstrates how the technology of the PRC and similar technologies of the regulation of mobility operate as practices of bordering and nation-making and constitute Canadian citizenship.
\end{abstract}

New technologies of surveillance and mobility regimes are turning individuals into data by digitizing body parts. The growing privatization of such security arrangements marks the prominence of an identity industrial complex that is increasingly aligned with the security imperatives of the United States and the European Union. The rationale behind these (preexisting) security imperatives is often purported as the consequence of the events of 11 September 2001 and the subsequent "war on terror". More alibi for heightened securitization than rationale, these events brought with them a refashioning of the conditionality of the status of those produced as "outsiders", and in the case examined in this article the conditionality of the status of the Canadian permanent resident. Within such security regimes, the body comes to function as text, or as document (Lyon, 2001). My concern in this article is in learning how documentary procedures, particularly Canada's Permanent Resident Card (PRC) and important events surrounding its introduction, turn people and bodies into differentiated and identifiable state subjects and data. My intention

Correspondence Address: Simone Browne, OISE/University of Toronto, Department of Sociology and Equity Studies in Education, 252 Bloor Street West, 12th floor, Toronto, ON M5S 1V6, Canada. Email: sbrowne@oise.utoronto.ca

1362-1025 Print/1469-3593 Online/05/040423-16 (C) 2005 Taylor \& Francis

DOI: $10.1080 / 13621020500211420$ 
here is to make the links between the ways in which modern power makes up populations and individuals and allows for practices of identification to emerge through visual and visualizing regimes that inscribe some individuals as "subjects", while marking others as "bodies". The PRC, while part of the bureaucratic governance of permanent residents as a population, is also part of the productive effort to create the unmarked Canadian citizen.

This article is organized as follows. In the first section, I provide a brief introduction to the PRC and what I see as its role in the transnational regime of border control. The second section outlines concepts that I employ, such as "border control" and "nationalization", and the term "economies of bodies". In the last section, I examine three key moments surrounding the PRC: excerpts from a parliamentary committee public hearing; the first PRC prototype to be released into the public domain; and using various Canadian print news media sources, I take a look at the experiences of some permanent residents, questioning the ways in which the management of transnational movement and access to the nation-state were meted out by way of the PRC. With identity documents serving as a key technology in the management of mobility, an examination of the bureaucratic production of the PRC as a state issued status document could provide insight into the processes of this particular aspect of state- and nation-formation. I am suggesting that the identification and classification achieved through the PRC help to write the nation on the body, and shape our individual and collective imaginings about citizenship and belonging to the nation.

\section{Section One}

\section{The Permanent Resident Card}

Canada's Permanent Resident Card was introduced with the Immigration and Refugee Protection Act (IRP Act), first tabled in the House of Commons in February 2001 and enacted 28 June 2002. The PRC is a proof-of-status document that replaces the paper IMM 1000 Record of Landing document. New immigrants to Canada are issued a card upon arrival. For those already situated in Canada, application for the card is voluntary, but the PRC is required for re-entry by commercial carrier into Canada for Canadian permanent residents as "secure proof" of their status. Interestingly, this re-entry rule has not always been equally enforced, as I will discuss in more detail below. In March 2004, Citizenship and Immigration Canada (CIC) reached the one million mark for cards issued. Approximately 1.5 million permanent residents live in Canada. As a more sophisticated technology than the contemporary Canadian passport, the PRC provides a laser engraved photo and lists the holder's date of birth, nationality, gender, eye colour, client identification number, and other eye-readable non-secure data. Other "personal information" is encrypted in an optical stripe and is said to be available only for the purview of authorized officials. Made from multilayer polycarbonate, the PRC holds 1.1 megabytes of digital data stored in a $16 \mathrm{~mm}$ optical memory stripe. In capacity, this is the equivalent of about 500 pages of data. Polycarbonate is a lightweight, durable plastic used in commercial applications. Visible on the optical memory stripe is an Embedded Hologram $^{\text {TM }}$ of the cardholder's picture, along with eye-readable data such as date of birth, country code of the cardholder's nationality, and the phrases "Property of the Government of Canada" and "Propriété du Gouvernement du Canada". Developed by LaserCard Corporation, the Embedded Hologram ${ }^{\mathrm{TM}}$ is said to be an anti-counterfeiting security 
device. ${ }^{1}$ Digital files that are machine-readable are encoded on the optical stripe, so that the optical stripe includes all information from the IMM1000 Record of Landing or Confirmation of Permanent Residence. Biometric data could be encoded within the card at a later date. Perhaps the most likely biometric technologies to be digitally encoded could be facial data and fingerprint data since the IRP Act requires that refugee claimants, who may later become permanent residents, be fingerprinted upon arrival in Canada. ${ }^{2}$

Some assumptions are made here. First, it is my assertion that claims to "legitimate" or normative citizenship are understood through the "bordering" of those depicted as potential threat to these citizenship claims and the rights to mobility and stability that come with them. In fact, according to CIC, the IRP Act is "tough on those who pose a threat to Canadian security". ${ }^{3}$ However, my interest lies with the mutually constitutive relationship between citizenship and those state subjecthoods that are considered "not so threatening", card-carrying members of the state, in this case the category of the "permanent resident". Second, I situate the PRC as part of a larger effort in the production of insecurity by a transnational regime of border control. The PRC is the world's first International Civil Aviation Organization (ICAO) standard compliant optical memory card. As well, the International Card Manufacturers Association awarded the PRC the 2002 Elan Award for Technical Achievement. Clearly, the transnational regime of border control is dependent upon the triangulated operations of private enterprise, states, and nongovernmental organizations, such as the ICAO. Furthermore, there is a mutually emergent and equally important player in the transnational regime of border control: the emotions of citizens, including fears, anxieties and imaginings. Third, in my view, identity documents such as the PRC "nationalize" immigrant bodies by codifying place of birth and country code. Seemingly, identity documents are one of the technologies that organize and function as the symbolic and material representations of how nationalization is delineated, and how categories of state subjecthood such as "citizen" and "permanent resident" are produced. I use the term "bodies" rather than people or individuals here not to deny ontological validity to those categorized as "permanent resident", but to point to the ways that the PRC fragments individuals and reduces them to bodies and body parts (sex, height, colour of eyes; and technology that could digitize permanent physical features, such as a fingerprint) for the purposes of what David Lyon terms "biosurveillance" (2001).

According to Anthony Richmond, "passports and visas no longer facilitate movement between countries but are instruments of exclusion" (2002, p. 716). For Richmond, these documents, as instruments of exclusion, work in conjunction with increasingly invasive surveillance technologies as part of "a formidable armoury of control devices" (p. 716). While agreeing with Richmond that technological advances dealing with the monitoring of mobility and population control often encroach on human rights, I am suggesting that these state issued status documents in general, and the PRC in particular, simultaneously function as instruments of inclusion and exclusion. This is an inclusion for citizens that is predicated on the exclusion of, often interchangeable, "others", in this case those categorized as "permanent residents" and undocumented "illegal migrants". To better understand how this apparent interchange operates, I look to Didier Bigo's model of a "stock exchange of security" where, as he put it:

if each security service uses the word immigrant as a sign of danger, a consensus is possible - because such a word can designate a foreigner as an Algerian (a member of an ethnic minority that may already have citizenship) or as other kinds of 
foreigner. Each country can then sell its fear to the other country (hence, Algerians come under surveillance in Britain and Germany, and Kurds in France and Britain). (2002, p. 71)

In such a model, "immigrant" is a signifier of danger or at least potential danger. Further, the fear of this presumed danger is commodified, marketed and used to propel what Bigo terms "the main technique of securitization". In Bigo's own words, this technique operates

to transform structural difficulties and transformations into elements permitting specific groups to be blamed, even before they have done anything, simply by categorizing them, anticipating profiles of risk from previous trends, and projecting them by generalization upon the potential behaviour of each individual pertaining to the risk category. (p. 81)

The point here is that, given this logic, a presumed danger can subsume an entire group through its categorization as such. Could this logic have prevailed during the parliamentary processes surrounding the creation of the PRC? Was the PRC the outcome of a "technique of securitization" where structural difficulties-in this case the need for "measures for preventing counterfeiting, forgery or fraudulent use of identity papers and travel documents" — were transformed by producing some as "risky bodies" needing mobility/identity documents to regulate them and to produce certain truths about them?

Much of the research on the functioning of mobility documents situates passports as markers of the bearer's allegiance to the issuing state, for example, Torpey (1998), O'Byrne (2001), and Adey (2004). Darren O'Byrne, for example, sees one of the functions of the passport as being that of a "political tool because it allows an administrative body to discriminate in terms of who can and cannot travel in its name" (2001, p. 403). For me, the PRC is a political tool in O'Byrne's sense. However, it is not about allegiance to the state but about calling the allegiance of the permanent resident into question. A look at the application procedure reveals how this questioning of allegiance is made possible.

\section{The Application}

In completing the PRC application (IMM 5444) the applicant must provide "ADDRESS, WORK AND EDUCATIONAL HISTORY" for the past five years. Each month must be accounted for. Sections cannot be left blank, as doing so could delay the processing of the application; instead "N/A" must be recorded where applicable, for example, during a time of unemployment. Since permanent residents are required to be physically present in Canada for a minimum of 730 days within each five-year period in order to fulfil residency requirements, the applicant must provide a detailed account of any absences from Canada, including vacations. The information booklet that accompanies the application notes that considerations may be made on compassionate and humanitarian grounds for those who have not fulfilled their residency obligations, inferring here that one's status can be revoked if the residency requirements are not met. The application document also requires the applicant to reveal "PERSONAL DETAILS" such as height, eye colour (six possible colours to choose from, as well as a box marked "other"), date of birth, marital status, 
country of citizenship, and given and family names. Interestingly, the information booklet notes that family names over 20 characters and given names over 15 characters will be automatically shortened due to space restraints. The application must be accompanied by a Supplementary Identification Form (IMM 5455) upon which must be affixed a $35 \times 45 \mathrm{~mm}$ photograph of the applicant. False hairpieces can be worn, as long as they do not disguise, what the application booklet terms the "natural appearance of the bearer" (IMM 5445E, Citizenship and Immigration Canada, 2004, p. 13). Tinted prescription glasses may be worn, but not sunglasses. Hats and hair coverings or "anything that interferes with the photo's value in providing a means of identifying the isuee for the benefit of travelling control, are not acceptable" (IMM 5445E, Citizenship and Immigration Canada, 2002, p. 11). However, exceptions are made for religious headgear. ${ }^{5}$ Unlike the requirements for the Canadian passport photograph, the "no smile rule" is not in effect.

Given the above requirements and specifications, the process of filling out the IMM 5444 requires the applicant to produce a dossier of evidence, or a body of data, to substantiate her claims. Such a dossier comes to stand for the applicant, as a textualized representation of the subject that, along with the applicant's body data, once encoded on the optical stripe of the card, becomes the digitized intellectual property of the state. I term this intellectual property as belonging to the state because the application states that "the Permanent Resident Card issued by Citizenship and Immigration Canada remains at all times the property of the Government of Canada and must be returned to Citizenship and Immigration Canada at its request" (Application, 2004, p. 3). As such, through the completion of the application procedure, the applicant produces herself as a "responsible immigrant", a responsible immigrant being one who can account for her employment, residences, comings and goings, and who can provide a guarantor to verify her claims. Importantly, this concept of a guarantor, a Canadian citizen who can vouch for the applicant, is a key subject in this making of the responsible immigrant. Without suitable details, the applicant's allegiance to the state is questioned, with the possibility of undergoing a special review through the Quality Assurance Program. This calling of allegiance into question that is achieved by way of the application process is significant as it points to rights to mobility and stability and the distinct relation of these rights to power, self-government and the making of the responsible immigrant. Here the restriction of mobility is an effect of power. As well, the application process points to the conditionality of this particular immigrant status, a status that requires accountability. Conditional in that the card is only valid for five years, this is a type of inclusion that is dependent on fulfilling particular responsibilities and that requires the repetitive production of the applicant as responsible and accountable. Given this, the application is one technology that allows permanent residents to produce themselves as "responsible immigrants". Through this processing, from application to the finished personalized card, the body of data and the body data become a commodity that brings together both the subject and the body. I use the term commodity here as these data are surrendered and exchanged for mobility rights and access to movement. The card accounts for the subject, and with the possible addition of biometrics, the card could produce an ontological and scientific "truth" of its holder. If the production of the responsible immigrant takes place through the application procedure and the production of the card, it can also be said that this process, with its organizing, managing and serializing of the permanent resident, also produces the citizen, as an unmarked Canadian with less restrictive mobility rights. 


\section{Section Two}

\section{Border Control and Economies of Bodies}

In examining the discourses and practices of border control and how they were put into effect in the production of the PRC, it is important to focus on the particularization of bodies within the nation-state. Particularization, for the purposes of this paper, occurs by way of the categorization and investment of gendered and racialized meanings to certain bodies. Through the process of particularization, some groups and individuals are apparently fixed and made known as being within the Canadian nation-state. My concern here is with those individuals and groups that come to occupy the position of outsiderwithin status in the nation-state, and the ways in which this outsider-within status shapes how citizenship and other forms of state subjecthood are constituted. The term "state subjecthood" encompasses a variety of subject positions, including citizens, immigrants, migrant workers, refugees, temporary visitors, visa holders, as well as the undocumented. Also, the notion of "bordering" as articulated by Sunera Thobani (2000) is an important concept to understand. Bordering occurs through the situating of particular bodies as "outsiders" that symbolically demarcate the nation and who belongs to it. This differentiating of bodies takes symbolic, discursive and material forms with the aim of achieving particular kinds of subjects, often in gendered, racialized and sexually specific ways. As such, I situate bordering as one of the key disciplinary practices of the nationstate, with classificatory identity/mobility documents playing an important role. These documents not only regulate mobility and access to space, but they do the organizing work of "fixing" identities. This "fixing" is one element of border control. While the greater imperative of border control is the security of both geopolitical and financial space, the term also signals the operational dynamics by which the state regulates mobility and sometimes confines some bodies within the state, while deterring other bodies outside of the state from entry. It is a process that is not singular, but one that shifts according to the historical moment. These operational dynamics have both material and ideological implications. In this way, "border control" suggests the bordering of particular individuals, groups and bodies, referred to above, that at once situates these bodies as outsider-within the nation-state with the function of determining how the citizen comes to know itself as "citizen". A useful way to think about citizenship here is that it does the work of bordering "members of a polity from another as well as members of a polity from non-members" (Isin \& Wood, 1999, p. 20).

The state, through its policy-making, administrative practices, judicial system and other regulatory practices, helps to shape the nation and to give it the appearance of order. By way of but not solely through this shaping, ideologies and imaginings of the "nation" are made possible. Some individuals and groups are bordered, racialized, de-racialized and nationalized as members of the nation-state, while others are ascribed an outsider or outsider-within status along with the penalties that come with this status. The practice of nationalization, or of "being nationalized", is understood here as the fixing of particular individuals as belonging to Canada's geopolitical space, while other individuals are fixed as belonging to other geopolitical spaces, even though such individuals may be located in Canada. In this practice, the individual is inscribed with a certain subjectivity, nationalizing her as she is differentiated from others. Following Radhika Mongia (1999), nationalizing can be understood as a practice of racialization, where individuals are particularized in totalizing groupings and attributed essential racial meanings. I am 
suggesting that identity documents, such as the PRC, are one of the technologies that organize and serve as the symbolic and material representations of how nationalization is delineated. For more insight on the working of nationalization, I turn to Orvar Löfgren's (1999) suggestion that the anxiety that comes with the passport regime is one that is accompanied by the "nationalizing gaze" cast by border control and customs officials. To this understanding I would add the disembodied nationalizing gaze cast by surveillance technologies, such as verification machines, that read passports and other identity documents for the purpose of sorting their bearers. Similarly, Peter Adey (2004) suggests that passports make a person "legible" to the state as they are markers of the holder's identity and of the limits, or limitlessness, to the holder's spatial mobility. Is such legibility encoded in the PRC? Perhaps the nationalizing gaze, cast by customs officials and verification machines, is also achieved by the PRC's marking of country code representing its holder's place of birth. Here, the nationalizing gaze is part of the making of a "PRC identity" where the body functions as text and one is compelled to live up to this identity, in order to re-enter Canada from travel abroad, and increasingly for access to other benefits from the state. ${ }^{6}$

The term "economies of bodies and body parts" signals a system whereby body data is digitized by way of disciplinary mechanisms to, borrowing from Michel Foucault, "work the body retail" (1979, p. 137) for the production of normalized, docile bodies. Here "retail" signals individualizing processes. Within this system, the body, and increasingly digitized parts and pieces of the body are not only worked retail, but are also worked wholesale in databases (criminal databases, soccer "hooligan" databases, permanent resident databases, "suspect terrorist" databases). These parts and pieces are circulated through transnational spaces, traded (as suggested by Bigo's "stock exchange of security"; Bigo, 2002), commodified by private corporations that market some populations as "risky" and who develop security technologies capable of making some permanent physical features and behavioural traits, or body data, into digitized intellectual property. Also, there exists the possibility of identity documents capturing counterfeited body data. That being said, the term points to a set of interrelated activities where bodies are both produced and consumed. Below, I outline key concepts that lend clarity to the term "economies of bodies". I suggest we can find these concepts in Michel Foucault's discussions on reason of state and disciplinary society.

In "The political technology of individuals" (1988) Foucault poses the following question:

Which kind of political techniques, which technology of government, has been put to work and used and developed in the general framework of the reason of state in order to make of the individual a significant element for the state? (p. 153)

This question is important for in its answer lies the means through which we come, as Foucault notes, "to recognise ourselves as a society, as part of a social entity, as part of a nation or state" (p. 146). In this work, Foucault sets out to explain "reason of state" and he deals with the seventeenth century emergence of the modern political subject. Foucault's concern, in this work and others, was with a subject that was strictly bourgeois, European and male (1990a, 1990b). For Foucault, reason of state is "a technique conforming to certain rules" within which "the art of governing people is rationale on the condition that it observes the nature of what is governed, that is the state itself" (1988, p. 149). In other 
words, the ways in which a population is governed by the state are contingent upon that state's own preservation. For Foucault, the means and techniques through which the modern state achieves its goal of population management are dependant upon the modern state acting on the interest of the population "at the level of the consciousness of each individual who goes to make up the population, and interest considered as the interest of the population regardless of what the particular interests and aspirations may be of the individuals who compose it" (p. 100). For Foucault, this particular art of governing is tied with the emergence of what he calls "political arithmetic" where statistics deal not with probability, but with the "knowledge of the state", its strength, and that of other states' respective powers (p. 151). In this way, states were conceived of as continually having to preserve themselves through correct governance. How so? The form that this correct governance assumes and the rationale behind it is linked to one "idea" that Foucault develops from reason of state, which is that under the conditions where the state is continually concerned with its preservation, "the individual becomes pertinent for the state insofar as he can do something for the strength of the state" (p. 152). With this idea, Foucault raises the question of the individual's political utility:

The individual exists insofar as what he does is able to introduce even a minimal change in the strength of the state, either in a positive or in a negative direction. It is only insofar as an individual is able to introduce this change that the state has to do with him. And sometimes what he has to do for the state is to live, to work, to produce, to consume; and sometimes what he has to do is to die. (p. 152)

At the heart of this is the suggestion that reason of state is concerned with what Foucault terms the "happiness" of individuals. This is a happiness where the police see to making people into, and sustaining them as, useful state subjects. ${ }^{7}$ We can interpret from the above quote that individuals, living as part of a population within the environment as a social body, and their experience of "happiness" on which the state depends, can be done away with as this is a political rationality under which the strength of the state must be preserved. In this case, the question of political utility arises. If the individual only exists to the extent that she can introduce a change in the strength of the state, then discipline is the thing that determines her utility.

Foucault opines that the political rationality of our time is one where the processes of the integration of individuals into the political totality are characterized by a constant correlation between an increasing individualization and the reinforcement of this totality (pp. 161-162). With such a rationality, techniques of reason of state are employed to bring about the docility of individuals. Here the state is concerned with the "happiness" of individuals, as well as with its own preservation. In other words, the state is concerned simultaneously with technologies of the self and with disciplinary technologies. These are technologies that reinforce each other, in an effort to know the individual, have the individual know herself in order to facilitate self-government, and to submit her to certain practices for the production of a docile body. As such, this is an effort at working the body retail by way of disciplinary techniques. Through these techniques, what Foucault terms "simple instruments" - techniques of identification, registration, hierarchical observation, normalizing judgment, correct training - the individual is made known as a subject. Although disciplinary power is individualizing, through normalizing judgment individual actions are referred "to a whole that is at once a field of comparison, a space of 
differentiation and the principle of a rule to be followed" (1979, p. 182). Here the examination is important as it orders and "establishes over individuals a visibility through which one differentiates them and judges them" (p. 184). Foucault argues that

the examination that places individuals in a field of surveillance also situates them in a network of writing; it engages them in a whole mass of documents that capture and fix them. The procedures of examination were accompanied at the same time by a system of intense registration and of documentary accumulation. A "power of writing" was constituted as an essential part in the mechanisms of discipline. (p. 189)

Further, Foucault notes that disciplinary power is "exercised through its invisibility", while imposing a "compulsory visibility" on its targets (p. 187). So disciplinary power can be said to operate, at times, as a visual and visualizing regime where "documentary accumulation" and "a network of writing" are put into practice to produce a scrutinizing surveillance that individuals are at once subjected to, and that produces them as subjects. It is with this understanding of the operational dynamics of visual regimes in disciplinary society that I wish to situate my query of how identity documents function to nationalize individuals through the individualizing and essentializing processes of particularization. These documents by way of a visual and visualizing regime facilitate the state's ability to serialize and "fix" individuals and sometimes control their transnational movements, or at least what the state defines as legitimate movement.

\section{Section Three}

In November 2002, then immigration minister Denis Coderre put forward a recommendation for a national debate on the issue of identity cards for all Canadians. Proposing that such a card would be similar to the PRC, Coderre noted that "identity has taken on new prominence" since the events of 11 September 2001. He also suggested that debating an identity card would provide the opportunity "to clarify what it means to be a citizen, a Canadian" (Coderre, 2003). Coderre's call led to the Biometrics: Implications and Applications for Citizenship and Immigration forum held by CIC in October 2003. Government officials, participants from the private sector and other "experts" attended this by-invitation-only forum. Coderre's suggestion of a national identity card was met with critique. The former Privacy Commissioner of Canada in his Overview of the Annual Report to Parliament declared, among other things, that a national identity card would create "Big Brother dossiers" that could "open the way to being stopped in the streets by police and required to identify ourselves on demand" (Radwanski, 2003, p. 3). The national identity card did not move beyond debate, however Coderre's recommendation was not the first instance of such a call. One occasion in particular had certain elements in common with Coderre's, namely, the suggestion that the card would thwart terrorists. A Notice of Motion was filed in October 1971 in the House of Commons considering the "Compulsory Carrying of Identification Cards" for Canadian citizens and immigrants. Filed by Member of Parliament Fernand Leblanc, this motion was in response to the 1970 events known as the October Crisis involving the Front de Libération du Québec (FLQ), the kidnapping and killing of Quebec Justice Minister Pierre Laporte, the kidnapping of British Trade Commissioner James Cross and the invoking of the War Measures Act by 
the federal government. Leblanc noted that "such a card could ensure the protection of the community in case of riots and terrorist acts", while one MP argued that the motion be "examined from every angle with very long tongs, and then dropped into a furnace and burned" (Leblanc, 1971).

\section{Parliament as a Site of Discursive Production}

Why parliamentary processes as a site for analysis? To briefly answer this I turn to Benedict Anderson's suggestion that "individually, legislators represent particular interests, localities, and prejudices; collectively and anonymously, as Parliament, Diet, or Congress, they represent a unitary nation or sovereignty" (1994, p. 319). By examining the procedures through which Members of Parliament legitimize the idea that they represent a unitary nation, such a presumed anonymity can be challenged. As well, examining select parliamentary processes can point to the conditions that made the PRC possible and can uncover documentary evidence of the methods of bureaucratic decision-making in the policy-formation process. I suggest that by examining the parliamentary discursive practices that shaped policy-formation and legitimized the creation of the PRC, we can learn how the categorization of some as "permanent residents" shapes understandings of Canadian citizenship and the borders of the nation. Along with press releases, policy papers, speeches from the throne, and press conferences, Standing Committee meetings are parliamentary processes of truthmaking and knowledge production. What follows are verbatim excerpts from the Standing Committee on Citizenship and Immigration meeting on 9 February 2000. During this meeting, the Standing Committee conducted hearings on the refugee determination system and "illegal" migrants. Representatives from non-governmental organizations presented to the Committee after their submission of consultative documents.

Mr. Warren Everson (Vice-President, Policy and Strategic Planning, Air Transport Association of Canada): /. . /One particularly frustrating and expensive problem that is getting worse by the day is the fraudulent use of genuine Canadian IMM 1000 resident cards by illegal migrants. The cards are notorious for their vulnerability to fraudulent use. There is no photo ID on the document. The IMM 1000 incorporates no modern validation techniques. In short, it's an open invitation to manipulation by professional movers of illegal migrants. It's impossible for airline personnel to detect when a genuine Canadian IMM 1000 is fraudulently used in combination with a genuine foreign passport. CIC nevertheless subjects our carriers to financial penalties when that card is used by arriving passengers who are subsequently identified as inadmissible.

... So if there is a single recommendation that we think this committee could make that would help the airlines reduce the fraudulent use of the Canadian document, it would be to insist on a replacement of the card with a document that uses currently available technology.

Here it is made known through "expert" testimony that the imperatives of ATAC, a nongovernmental organization, regarding border control and the deterring of illegal migration 
to Canada are aligned with those of the state. The borders of the state are represented as particularly porous, due to the "problems" caused by the easily forged IMM 1000 that are exploited by "professional movers of illegal migrants". With the suggestion that new technologies be employed to control the flow of illegal migrants, we can understand this Standing Committee meeting as a social event where, what I referred to earlier as, the triangulated operations of states, non-governmental organizations and private enterprise in the transnational regime of border control are put into practice.

Mr. Leon Benoit (Director, Government and Industry Affairs; Legal Counsel, Air Transat, Air Transport Association of Canada): ... I might remind you, as we mentioned before, that airport authorities in other countries aren't always very willing to listen to our problems in terms of what we have to do under Canadian legislation.

There is a fundamental issue in some countries-I won't name them-where clearly the country in question has absolutely no interest in helping you stop that person from getting on your flight, leaving their territory and going to Canada, because basically they have just eliminated another problem for themselves. We operate in that sort of environment. So I think we are making that effort.

On this issue of a scanner, I would like to know what you think this thing could do. I am just asking how this would work. Would this be something-

The Chair (Mr. Joe Fontana (London North Centre, Liberal)): Scan their eyeballs.

Mr. George Petsikas (Director, Government and Industry Affairs; Legal Counsel, Air Transat, Air Transport Association of Canada): As long as it doesn't induce blindness, that's fine.

Mr. Steve Mahoney (Mississauga West, Liberal): That's not what it would do, Mr. Chairman.

From this excerpt, we can begin to see that blame for the "problem" of the undocumented is placed both on "unnamed countries" that wish to "unload" their problems, and on the restrictions produced through Canadian legislation that could be understood here as seeming "too lenient". Also, there is the suggestion that such "problems" could be regulated through the use of a visualizing regime that employs surveillance technologies, such as the PRC and like practices, that rely on the notion that the body will reveal the "truth" about a person's identity despite the subject's claims.

The Chair: ... With most of the people who come to Canada wanting to claim refugee status, if they're coming directly by plane and landing in our airports or perhaps coming via the United States or wherever, obviously you ask these people for their proper documentation to make sure they can board the plane. That's notwithstanding the fact that you said some nations may very well be wanting to get rid of their problems and therefore they're prepared to do whatever. 
Ms. Jean Augustine (Etobicoke-Lakeshore, Lib.): There is one curiosity I have. With the stowaways, what is the profile? What is the age, sex? Could you give me the profile of a stowaway?

Ms. Sonia Simard (Manager, Policy and Government Affairs, Shipping Federation of Canada): What we have seen in recent years are mainly stowaways coming from Romania. More than $70 \%$ of our stowaways are coming from Romania and they are males under the age of 25 . So we do see a profile there.

In the above excerpts two important assumptions are revealed. First, the undocumented are produced as problems that sending nations wish to get rid of, and that are arriving at "our" airports. The use of "our" signals a sense of ownership and belonging to the nation and the citizenship rights that this belonging entails, as well it points to the fears and anxieties surrounding the idea of porous borders. In this way, certain bodies are understood as unlawfully invading social spaces that belong to citizens and other documented state subjects. Second, a profile of the recent stowaway is made known, the majority of who are gendered and nationalized as Romanian males. This nationalization of the stowaway is not a static process but one where the nation is interchangeable, as other "expert" testimonies that took place before the Standing Committee that same day centred on a discussion of Tamil asylum seekers. Seemingly mundane at first glance, Standing Committee meetings reveal a particular type of truth-making where testimony and opinions of "expert" witnesses are often produced as fact. In this particular meeting, the suggestion that the IMM 1000 be replaced with a more secure document marks the beginning of the remaking of the category "permanent resident", where the permanent resident is remade, through the PRC, in relation to the anticipated security "threats" attributed to illegal migrants.

\section{October 2001}

When former Citizenship and Immigration Minister Elinor Caplan first announced the PRC during a press conference held at the Canada-US border at Niagara Falls in October 2001, she stated that "we are not going to allow this border crossing, or any other, to be held economic hostage by terrorists" (Thompson, 2001). During this press conference, Caplan produced a prototype of the PRC that depicted a blonde-haired, most likely white woman listed as 17 years of age. The name on the card was listed as Ponnuthaureuithirai Jagatheswary, whose nationality was identified as LKA. LKA is the country code for Sri Lanka. A link can be made here between anxieties around imagined threats to national security, Caplan's narrative of the need for protection of the borders from terrorists (especially those said to pose a threat to the economy), and those who the state assigns suspect, or potential threat status to, expressed through country code. With this particular prototype and the announcement made during this press conference, Ponnuthaureuithirai Jagatheswary (whether a "real" individual or not) in particular, and Sri Lankan nationals in general, were bordered as threat to the nation and its economic relations with the United States. Here race is codified as nationality, revealed by the country code. Clearly, this is an example of nation profiling. Interestingly, the prototype now used in the promotional 
material for the PRC shows a racially ambiguous Kiki Latesa from the Bahamas, a seemingly more "benign" state than Sri Lanka with no viable secessionist movements.

\section{Travel Agency}

In order to address how access to the nation space is sometimes demarcated based on national origin, it is useful to examine how the PRC was first put into practice. Midnight 31 December 2003 marked the deadline when permanent residents would need a PRC to re-enter Canada by way of commercial carrier. Without a PRC or a temporary travel document issued at a Canadian visa office, permanent residents would be denied re-entry. Getting a temporary travel document could prove difficult. If one were in Albania, for example, the closest Canadian visa office where one could apply for a temporary travel document is in Rome, Italy. In December 2003, an email from an official at CIC sent to travel agents and tour operators was leaked to the news media (Thompson, 2003). Stating, "I am pleased to confirm that persons holding visa-exempt passports will not require a PR card and may board return flights in the normal way", this email revealed information in contrast to the official information available on the CIC website and through the PRC advertising campaign. These exempt countries included Australia, Japan, most European nations, and Britain. Holders of valid US green cards would be exempt also. ${ }^{8}$ In contrast, citizens of countries such as Algeria, Jamaica, Pakistan and Syria would be subject to the re-entry requirements. This restriction of mobility, in effect, bordered some and created two categories of permanent residents to which different practices were applied.

In a January 2004 interview with the Toronto Star, then immigration minister Judy Sgro reported that 82 people had been denied re-entry for not having a PRC (Frasier, 2004a). Sgro also credited the PRC for barring a Jamaican citizen, previously deported from Canada, who attempted to return using an allegedly fraudulent Record of Landing on 1 January 2004. Some newspapers and the online message board at www.settlement.org reported that enforcement of the re-entry rule was not equally meted out. Those reports noted that nationals from India, Poland, Hong Kong, and Taiwan scheduled on return flights to Canada were prohibited from boarding the aircrafts due to lack of a PRC, while certain others were allowed to board planes without the PRC after the 31 December deadline. The enforcement of the re-entry rule by airline officials demonstrates how agencies outside of the state serve as border control due to the obligation set out in the IRP Act that airlines and other commercial carriers must ensure that their passengers are properly documented. Some permanent residents found the requirement of the PRC, given a backlog in application processing, an unreasonable limit on their movement and were able to do something about it. For example, a university instructor wishing to attend the premiere of his opera in Pittsburgh, Pennsylvania was able to have his application processed in a manner quicker than most with the help of the Canadian Consulate in Buffalo and the constituency office of his Member of Parliament (Morris, 2004). In another case, the owner of a manufacturing company in Belleville, Ontario who had business to attend to in Germany and Italy expressed to the Toronto Star that "I have created jobs here, I have paid millions of dollars in taxes", and that he would take his chances using his German passport and Record of Landing (Frasier, 2004b). Also, many people were able to get around the re-entry rule by entering Canada by private vehicle at Canada-US border crossings. Given this apparent loophole, if the PRC is meant as a technology to "protect the borders", the process is definitely flawed. 


\section{Conclusion}

The "PRC identity" could be understood as one where the marking of "permanence" that the PRC achieves is rather temporary as the card is valid for five years, and points to a unique form of card-carrying, state subjecthood where the holder is not completely of the nation, but the possibility of membership is alluded to, and sometimes deferred. ${ }^{9}$ Capturing and fixing through "a network of writing" and a visualizing regime, the PRC does the organizing work of bordering immigrant bodies, in relation to citizens and undocumented peoples. Given this, borders and bordering can provide narratives of how citizenship is understood in the nation. This notion of bordering opens up the concept of the border from a fixed place to a verb or a process. As such, bordering does not only occur at the territorial boundaries of the nation-state, it can also be internal to it. Although fear, suspicion, anxiety and complacency are some of the emotional reactions to our present moment, spaces are continually being created where people question and sometimes resist "techniques of securitization" and the conversion of bodies into data. ${ }^{10}$ Such activities point to the shaping of alternate imaginings of our investment in and belonging to the nation.

\section{Notes}

1 The manufacturers of the PRC are the Canadian Bank Note Company, Limited (CBN) subcontracted with California based LaserCard Corporation, in partnership with Anteon Corporation. Also subcontracted is Information Spectrum Incorporated. The five-year subcontract with LaserCard Corporation was awarded with Canadian Bank Note in 2002. CBN prints and distributes the card from its facility in Ottawa, Canada.

2 Immigration and Refugee Protection Act c.16 (2) (a). According to a document released under the Access to Information Act request, Biometrics: CIC Business Requirements, the CIC intends to have two biometric identifiers in the card, with facial data as the primary one and fingerprint templates as the secondary identifier. In this way, the PRC would be similar in function to the US Department of State's Laser Visa Border Crossing Card, a multiple entry visa used by Mexican citizens to enter the US. This card, also produced by LaserCard Corporation, is used to biometrically verify the cardholder's identity through a one-to-one identification process between the cardholder and the encoded fingerprint data.

3 "Immigration and Refugee Protection Act", Citizenship and Immigration Canada website, available at: www.cic.gc.ca/english/irpa (accessed 5 December 2003).

4 United Nations Security Council Resolution 1373, September 2001.

5 In practice, this was not always the case. In July 2004 the Prime Minister announced that religious headscarves were acceptable after complaints that women were being forced to remove their religious headscarves to be photographed for their PRC upon arrival at Pierre Elliot Trudeau Airport in Dorval, Quebec (Hustak, 2004; Stanstna, 2004). Hair and ears are not considered "facial features".

6 Although the PRC was introduced as a mobility document, Social Development Canada now requires a PRC in order for permanent residents whose Records of Landing were issued before 28 June 1973 and after 27 June 2002 to obtain a Social Insurance Number (SIN) or to replace a damaged or lost SIN Card. Given this, the PRC can be understood as a measure of the Canadian state's imperative to not only manage access to geopolitical space of the nation, but increasingly to the nation's financial space as well. This is especially the case for homeless and underhoused persons, as SIN cards are needed to apply for numerous government benefits. The difficulties faced by homeless and underhoused peoples in accessing the PRC are many. These include accessing the application form by Internet or by mail to a fixed address; payment of the application fee; accounting for employment and residence histories; securing a guarantor; and care of the application and photograph, which could be rejected if torn, bent or otherwise flawed.

7 See Foucault's discussion of Nicolas Delamare's Traité de la police (1705) (Foucault, 1988, pp. 153157) where the police are said to "see to everything regulating society" and "everything pertaining to 
men's happiness" (p. 157) where through the technique of the police the "integration of individuals in the state's utility is achieved" (p. 153). In a development on Delamare's work of systematizing French administrative practices, Foucault suggests that this is a project that through its classification of needs attempts to determine "the correlation between the utility scale for individuals and the utility scale for the state" (p. 157). For Foucault, reviewing Delamare's manual is instructive because in it Delamare positions human happiness as a political object (p. 158). Or as Foucault put it: "Now happiness is not only a simple effect. Happiness of individuals is a requirement for the survival and development of the state. It is a condition, it is an instrument, and not simply a consequence. People's happiness becomes an element of state strength" (p. 158).

8 A complete list of exempt countries and those whose nationals require visas can be found at: http:// www.cic.gc.ca/english/visit/visas.html

${ }^{9}$ In a survey conducted with permanent residents, some respondents said that they would not apply for the PRC within the first two years of its introduction (Environics Research Group, 2003).

10 A class action lawsuit involving 46 permanent residents was filed on 18 December 2003 claiming that the CIC engaged in systematic discrimination of permanent residents based on their nationalities (The Province, 2004). The application was dismissed in April 2004.

\section{References}

Adey, P. (2004) Secured and sorted mobilities: examples from the airport, Surveillance \& Society, 1(4), pp. 500-519.

Anderson, B. (1991) Imagined Communities (London: Verso).

Anderson, B. (1994) Exodus, Critical Inquiry, 20, pp. 314-327.

Bigo, D. (2002) Security and immigration: toward a critique of the governmentality of unease, Alternatives: Global, Local Political, 27(1), pp. 63-92.

Canada (2002) House of Commons debates (Hansard), Number 026, 18 November.

Citizenship and Immigration Canada (2002) Applying for a Permanent Resident Card form IMM 5445E.

Citizenship and Immigration Canada (2004) Applying for a Permanent Resident Card form IMM 5445E.

Coderre, D. (2003) Why discuss a national identity card?, Minister's speech, appearance before the Standing Committee on Citizenship and Immigration, 6 February 2003.

Environics Research Group (2003) Permanent Resident Card Advertisement Recall: Final Report (Ottawa: Environics Research Group).

Foucault, M. (1979) Discipline and Punish: The Birth of the Prison (New York: Vintage Books).

Foucault, M. (1988) The political technology of individuals, in: L. H. Martin et al. (Eds) Technologies of the Self: A Seminar with Michel Foucault (Amherst: University of Massachusetts Press).

Foucault, M. (1990a) The History of Sexuality: An Introduction-Volume One (New York: Vintage Books).

Foucault, M. (1990b) The Use of Pleasure: The History of Sexuality-Volume Two (New York: Vintage Books).

Frasier, G. (2004a) Controversial card keeps out criminal; deportee was barred from flight to Canada Sgro cites success of permanent resident ID, The Toronto Star, 19 January, p. A14.

Frasier, G. (2004b) Man to take his chances with no card, The Toronto Star, 26 January, p. A6.

Hustak, A. (2004) Muslim women arriving in Canada need not remove hijab at security check, PM says, National Post, 14 August, p. A5.

Isin, E. F. \& Wood, P. K. (1999) Citizenship \& Identity (London: Sage).

LaserCard (2004) LaserCard wire: newsletter, available at: www.lasercard.com/downloads/wire/013 April_2004_pdf(accessed 20 September 2004).

Leblanc, F. (1971), Canada. House of Commons debates (Hansard), 8 October, pp. 8572-8578.

Löfgren, O. (1999) Crossing borders: the nationalization of anxiety, Ethnologia Scandinavica: A Journal for Nordic Ethnology, 29, pp. 5-27.

Lyon, D. (2001) Under my skin: from identification papers to body surveillance, in: J. Caplan \& J. Torpey (Eds) Documenting Individual Identity: The Development of State Practices in the Modern World (Princeton, NJ: Princeton University Press).

Mongia, R. (1999) Race, nationality, mobility: a history of the passport, Public Culture, 11(3), pp. 527-555.

Morris, M. (2004) Have card, will travel, The Globe and Mail, 10 January, p. A19.

O'Byrne, D. (2001) On passports and border controls, Annals of Tourism Research, 28(2), pp. 399-416.

Province, The (2004) Airline passengers without new travel card denied re-entry into Canada, 2 January, p. A14. 


\section{S. Browne}

Radwanski, G. (2003) Commissioner's overview, in: Annual Report to Parliament 2001-2002 (Ottawa: Privacy Commissioner of Canada)

Richmond, A. H. (2002) Globalization: implications for immigrants and refugees, Ethnic and Racial Studies, 25(5), pp. 707-727.

Standing Committee on Citizenship and Immigration (2000) Evidence 36th Parliament, 2nd Session, 9 February.

Stastna, K. (2004) Hijab hassle haunts airport, The Gazette, 26 June p. A7.

Thobani, S. (2000) Nationalizing Canadians: bordering immigrant women in the late twentieth century, Canadian Journal of Women and the Law, 12(2), pp. 279-312.

Thompson, A. (2001) Immigrant ID reflects "changed world", Toronto Star, 13 October p. A1.

Thompson, A. (2003) Resident rules eased: official, Toronto Star, 14 December p. A1.

Torpey, J. (1998) Coming and going: on the state monopolization of the legitimate "means of movement", Sociological Theory, 16(3), pp. 239-259.

United Nations (2001) Security Council unanimously adopts wide-ranging anti-terrorism resolution; calls for suppressing financing, improving international cooperation, Press Release SC/7158, available at: http:// www.un.org/News/Press/docs/2001/sc7158.doc.htm (accessed 8 August 2002). 
Copyright of Citizenship Studies is the property of Taylor \& Francis Ltd. The copyright in an individual article may be maintained by the author in certain cases. Content may not be copied or emailed to multiple sites or posted to a listserv without the copyright holder's express written permission. However, users may print, download, or email articles for individual use. 